collection of pictures borrowed from art galleries in Europe and North America, interspersed with sculpture much of which has been borrowed from egyptologists and other students of the past. There is also a striking piece of modern building in which 158 living apartments have been assembled out of prefabricated concrete boxes, which are piled on top of each other with some of the informal abandon of toy building bricks. This synthetic village has something in common with many of the old casbahs in North Africa, but is also plainly a place made with modern concrete. It is hard to see how those who trudge around will fail to be persuaded that there is no necessary incompatibility between modern building methods and the idiosyncratic tendencies of real people. A great many will wish that they could settle permanently in what the fair calls Habitat.

The exuberance which runs through this and other parts of the exhibition is infectious, and the American pavilion has been properly applauded for its gaiety and wit. This is why it is particularly disappointing that the most ponderous parts of the whole exhibition are those which embody the fair's own scientific exhibition. Where the rest of the exhibition works mostly by subtle suggestion, the scientists are unfortunately too often didactic. Panoramas abound. There is a darkened structure filled with lighted tubes and packages in which visitors can stand to be instructed in the workings of what purports to be a living cell, but the chances are that the commentary will not mean much to those who have neglected to mug up on mitochondria in advance. The live (or partly living) preparations of Euglena under half a dozen microscopes are better value. The elaborate model of the human brain is a model-maker's triumph but such that here again a brief course of private study will be necessary if people are to get much from it. The physical sciences may be easier to come to grips with, chiefly because there are real things to show, though here again the visitor who is not also a specialist will have to dig hard for a few pieces of understanding. What seems to have happened is that the organizers have designed a splendid kind of science museum-the sort of place to which people can return and browseand that they have somehow failed to epitomize and to communicate a sense of how research has helped and is helping to transform the quality of life. 'T'o say this is not to complain, for they have done a splendid job of exposition which is disappointing chiefly because there is so much elsewhere that sparkles.

\section{Thrombosis and the Pill}

THe report of the Platt sub-committee to the Medical Research Council will undoubtedly cause some heartsearching among scrupulous doctors ("Risk of Thromboembolic Disease in Women Taking Oral Contraceptives", Brit. Med. J., ii, 355, 1967). The committee's conclusion carries the case against the "pill" a stage further than other such reports have done in the past; the report states that "there can be no reasonable doubt that some types of thrombocmbolic disorder are associated with the use of oral contraceptives". On the other hand, the qualifications of this conclusion are almost as important as the conclusion itself. The risk involved is small-indeed, some very pretty statistical manoeuvres were necessary before any conclusions could be reached from the small number of thromboembolic episodes available for study. The risk of thromboembolic disorder in women taking the pill is roughly twice that facing an equivalent set of women who are not pregnant and not taking oral contraceptives. On the other hand, the risk facing women who are pregnant is about twice that due to oral contraceptives. The report estimates that oral contraceptives may have caused about twenty deaths from venous thrombosis and pulmonary embolism in 1966. There is no firm evidence of any connexion between oral contraceptives and cerebrovascular disease, although such a connexion may exist.

Oral contraceptives, in one form or another, have clearly come to stay, and the report is unlikely to cause an important decrease in the number of women using these preparations. What is clear, however, is that doctors are likely to be more cautious in prescribing the pill to women with a history of venous thrombosis. More research is needed to clarify which women are likely to suffer from the effects of oral contraceptives, and the work now in progress on lowdose oral contraceptives is likely to be pushed forward faster.

\section{Information for Biologists}

INFORMATION problems in the biological soiences are now being studied by the recently formed Committee on Biological Information. The new committee, set up as a result of a conference on communication in the Biological Sciences, has representatives from the institute, Aslib, and the Biological Council. Its members are Miss P. I. Edwards, B. J. Perry and L. Wilson (Aslib), C. Pettit, A. G. A. Pickford and A. B. Standfast (Biological Council), and E. O. Pearson, P. C. Williams and H. V. Wyatt (Institute of Biology).

At a preliminary meeting attended by an observer from the Office of Scientific and Technical Information, a broad plan of attack was agreed. By a combination of working parties, research projects and small informal conferences the following problems will be investigated: the burial and attempted resurrection of the information in theses; the usefulness of the Style Manual for Biological Journals; reprint and copyright problems; the form of abbreviated titles for journals; the ranking of journals into primary, secondary, or mixed publications; the lack of training in library and literature usage in university courses, and the general ignorance of the ways in which biologists actually get hold of their information. These problems have yet to be given an order of priority. Liaison is being established with the Conference of Editors of European Biological Journals and with the U.S. Council for Biological Information. Biologists with bright ideas-or complaints-about the present situation are invited to write to the Secretary of the Committee, at the Institute of Biology, 41 Queen's Gate, Tondon, S.W.7.

\section{Encouraging Spin-off}

THE Ministry of Technology is to make another attempt to convince industry that the work supported in government laboratories is useful to it. The ministry is 